Papers and Proceedings of the Royal Society of Tasmania, Vo1.109, 1975.

(ms. received 26.6 .1974 )

\title{
CAMBRIAN STRATIGRAPHY OF THE ST. VALENTINES PEAK AREA, NORTH-WESTERN TASMANIA
}

by J.B. Jago,

Department of Applied Geology, South Australian Institute of Technology,

G.A. Pike,

Mt. Lawley Teachers College, Mt. Lawley, Western Australia,

and D. Mills,

Geology Department, University of Tasmania.

(with three text-figures)

\section{ABSTRACT}

An important Late Middle Cambrian fossil locality occurs $2 \mathrm{~km}$ west of $\mathrm{St}$. valentines Peak in north-western Tasmania. The Cambrian rocks to the north and west of St. Valentines Peak are exposed in the core of the north-south trending $S t$. valentines Peak Anticline. In the best exposed section ( $3 \mathrm{~km}$ north of the main fossil locality), the oldest Cambrian unit is a massive, cherty, pyritic meta-sandstone and meta-siltstone at 1 east $100 \mathrm{~m}$ thick. This is overlain by $100 \mathrm{~m}$ of rhyolitic welded tuff, 75 to $100 \mathrm{~m}$ of meta-sandstones and meta-siltstones, $100 \mathrm{~m}$ of a possible contact metasomatic rock and 230 to $375 \mathrm{~m}$ of a pale grey chert which in turn is overlain by about $17 \mathrm{~m}$ of fine breccia and poorly fossiliferous siltstone. This sequence is overlain with probable disconformity by the basal chert conglomerate of the essentially Ordovician Junee Group. It is suggested that the sediments of the main fossiliferous locality occur stratigraphically below the section noted above. The Cambrian and Ordovician rocks are intruded by Devonian granite and partly overlain by Tertiary basa1t.

\section{INTRODUCTION}

The purpose of this paper is to give a brief outline of the Cambrian geology of the St. Valentines Peak area. This area is important because in $1963 \mathrm{G}$. Pike discovered some of the best preserved Cambrian fossils in Tasmania in a deeply weathered siltstone near the corner of Hampshire Park Road and Gin Creek Road ( $1 \mathrm{at} .41^{\circ} 21.6^{\mathrm{t}} \mathrm{S}, 10 \mathrm{ng}$. $\left.145^{\circ} 44.3^{\prime} \mathrm{E}\right)$. The fossils were discovered subsequent to the reviews of the Tasmanian Cambrian System by Banks $(1956,1962)$. During the last ten years the writers have independently mapped the area for various purposes. Pike did the initial work and produced the first regional geological map of the St. Valentines Peak area; Mil 1s considered the area in relation to the mineralization around the Hampshire Hilis Granite; Jago mapped the area for biostratigraphic purposes.

The Cambrian rocks of the St. Valentines Peak area are poorly exposed with a thick vegetation cover in some places. Road cuttings and quarries are the principal sources of geological information.

\section{CAMBRIAN STRATIGRAPHY}

The Cambrian rocks to the north and west of St. Valentines Peak are exposed in the core of the essentially north-south trending St. Valentines Anticline (fig. 1). They are overlain with apparent conformity, but with probable disconformity, by a chert conglomerate which is the basal member of the Junee Group in this area. These sediments were later intruded by Devonian granite and finally partly covered by Tert- 
iary basalt.

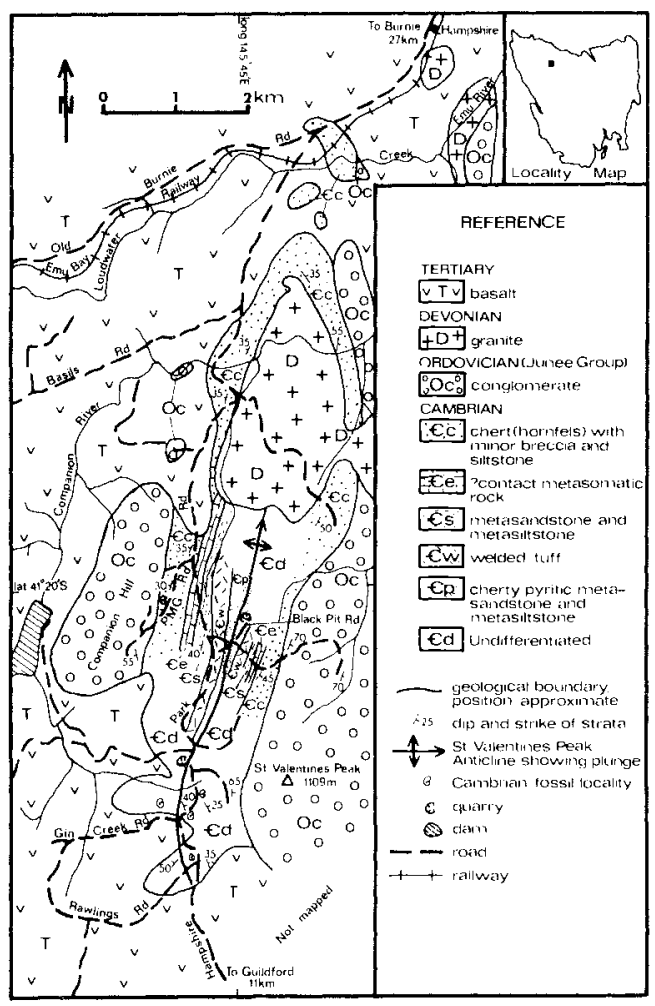

FIG. 1. - Geology of the St. Valentines Peak Area.
The best exposed sections are along the PMG Road, Black Pit Road and adjacent roads, and along Hampshire Park Road between PMG Road and Black Pit Road, (fig. 1). North of this area the Cambrian rocks are largely covered by basalt or intruded by granite; south of this area there is considerably less outcrop even in road cuttings. The stratigraphic column for the western $1 \mathrm{imb}$ of the anticline in the PMG RoadBlack Pit Road area is described below and sumnarized in figure 2. No formal stratigraphic nomenclature is set up due to the rather poor outcrop and the small size of the mapped area.

The lowest unit exposed in the PMG Road-Black Pit Road area is a massive cherty, pyritic meta-sandstone and meta-siltstone (at least $100 \mathrm{~m}$ thick) which is well exposed in the quarry at the end of Black Pit Road. The overlying unit is a devitrified incipiently to moderately welded tuff of rhyolitic to rhyodacite composition. Devitrified cuspate shards are common in the ground mass; there are some small recrystallized spherulites; the quartz phenocrysts are angular to rounded. The whole assemblage is typical of an ash flow. This unit is about $100 \mathrm{~m}$ thick.

The welded tuff is overlain by about 75 to $100 \mathrm{~m}$ of poorly exposed meta-sandstones and meta-siltstones. The overlying unit is about $100 \mathrm{~m}$ thick. In outcrop it has a green and white striped appearance with the white stripes being more resistant to weathering. This unit is concordant with the surrounding units. In thin section the green parts of the rock are distinctly nodular and consist of epidote group minerals, diopside (?), minor amounts of scapolite, tremolite (reasonably common) and isolated nodules of vesuvianite. The white parts of the rock are much finer-grained and consist largely of a mineral, with low bi-refringence, which cannot be identified with certainty. Traces of carbonate and some clay are also present in the finer 
grained parts of the rock. The composition of the rock varies considerably over a short distance, but its overal1 appearance remains the same. This rock is possibly of contact metasomatic origin and may have been an impure limestone or dolomite which was affected by the intrusion of the Devonian granite.

The overlying unit is a hard laminated and non-laminated, slightly pyritic, pale grey chert (hornfels), which is about $375 \mathrm{~m}$ thick on the western $1 \mathrm{imb}$ of the anticline and about $230 \mathrm{~m}$ thick on the eastern $1 \mathrm{imb}$ of the anticline. The chert weathers to a buff-coloured siltstone. It is overlain by $1.5 \mathrm{~m}$ of deeply weathered brown siltstone and $11 \mathrm{~m}$ of grey siltstone.

Overlying the grey siltstone is a $50 \mathrm{~cm}$ lens of microbreccia which is separated by about $1 \mathrm{~m}$ of grey siltstone from a lens of breccia which varies from 15 to $45 \mathrm{~cm}$ in thickness over the $2 \mathrm{~m}$ in which it is exposed. This upper breccia lens consists of angular pebbles of chert and quartzite up to $2 \mathrm{~cm}$ across, but which average 0.5 to $1 \mathrm{~cm}$ across. It tends to be disconformable on the underlying siltstone.

The upper breccia lens is overlain by $3.5 \mathrm{~m}$ of poorly fossiliferous, micaceous grey-green siltstone and interbedded fine breccia beds. The fossils are unidentifiable brachiopod and trilobite fragments discovered at lat. $41^{\circ} 20.2$ 's, long. $145^{\circ} 44.1^{\prime} \mathrm{E}$. Despite intensive collecting, no recognisable trilobites have been found. The fossil iferous siltstone is separated from the basal Junee Group conglomerate by a 5 to $10 \mathrm{~cm}$ band of very fine grey siltstone.

The section across the contact between the Junee Group conglonerate and the sediments described above is shown in figure 3 . The contact is very sharp but is slightly uneven suggesting slight disconformity rather than conformity. The nature of the contact on the eastern side of the anticline where faulting makes interpretation difficult, is much less clear.

The main Cambrian fossil locality in St. Valentines peak area at 1 at. $41^{\circ} 21.6^{\prime} \mathrm{S}$, long. $145^{\circ} 44.3^{\prime} \mathrm{E}$ is about $3 \mathrm{~km}$ south of the section discussed above. Part of this fauna has been described (Jago 1972b; Jago and Daily 1974). Trilobites found at this locality include Schmalenseeia gostinensis, Nepea, a zacanthoid, Opsidiscus argusi, Peronopsis, Clavagnostus (?) rawlingi, Aspidagnostus, Agnostascus (?) and othe rs. This Late Middle Cambrian fauna is either of the Lejopyge Zaevigata III Zone of Opik (1961) or Öpik's (1967) Damesella torosa-Ascionepea janitmix Zone (Jago 1972b). The 
rocks of the southern part of the mapped area are shown in figure 1 as Cambrian Undifferentiated. They include deeply weathered meta-siltstones and meta-sandstones with some acid volcanics.

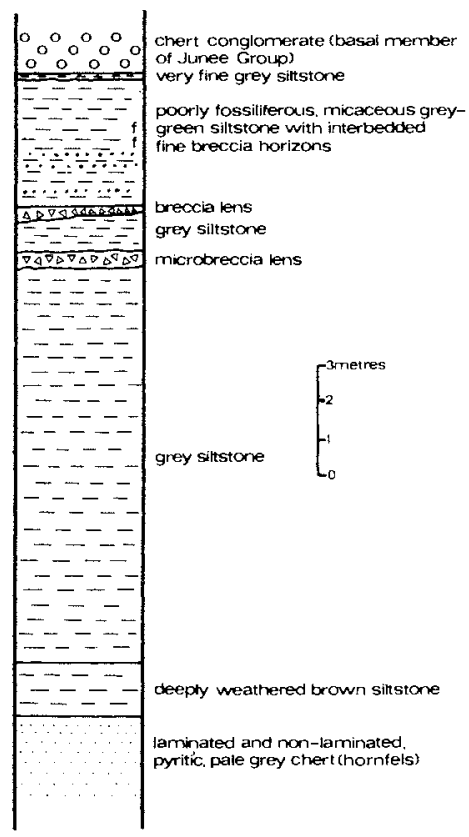

FIG. 3. - Cambrian-Junee Group contact, PMG Road, Companion Hill (lat. $41^{\circ}$ 20.2's, long. $\left.145^{\circ} 44.1^{\prime} \mathrm{E}\right)$.
In the area where the fauna noted above is found, the outcrop is very poor. In fact, the best fossils are found in sediments trapped in the roots of fallen trees. There are three other fossil localities in the immediate vicinity (fig. 1). All are found in road cuttings of the Hampshire Park Road. The central of these three localities appears to have a similar fauna to that noted above. The northernmost locality at lat. $41^{\circ}$ $21.4^{\prime} \mathrm{S}$, long. $145^{\circ} 44.6^{\prime} \mathrm{E}$ has only very poorly preserved fossils which include unidentified polymerid trilobites and Agnostascus (?). Its stratigraphic position indicates that it is slightly younger than the main fauna. The southernmost locality, at the junction of Hampshire Park Road and Rawlings Road is represented by a single poorly preserved agnostid pygidium.

The outcrop in the area where the main Late Middle Cambrian fauna is located is insufficient to determine its exact stratigraphic position with respect to the units of the PMG Road-Black Pit Road section. However, if the structure as shown in figure 1 is correct, then this fauna occurs stratigraphically slightly below the lowest unit of the PMG Road-Black Pit Road section (fig. 2). Concealed faults could alter the situation (as shown in fig. 2) so that the sediments of the main fossil locality correspond to some of the sediments from the PMG Road-Black Pit Road area. For example, they may correspond to either the "meta-sandstone and meta-siltstone" unit above the welded tuff or to the chert unit (which, as shown above, weathers to a siltstone) above the ?contact metasomatic rock. The latter possibility is supported to some extent by the slightly cherty nature of some of the deeply weathered meta-siltstone near the corner of Gin Creek Road and Hampshire Park Road. However, at present fossils such as those found in the southern part of the area are unknown from the PMG Road-Black Pit Road area, and the situation as shown in figure 2 is preferred.

\section{JUNEE GROUP CONGLOMERATE}

Descriptions and discussions of the Cambrian rocks of Tasmania have usually stopped at the base of the Junee Group most of which is of Ordovician age (Corbett and Banks 1974). However, it has become apparent that the basal parts of the Junee Group in different parts of Tasmania are probab1y Late Cambrian (Quilty 1971; Jago 1972a). 
J.B. Jago, G.A. Pike and D. Mills

Hence, a brief description of the basal Junee Group conglomerate from the St. Valentines Peak area is given below. The best exposures of this conglomerate occur on the PMG Road with additional outcrop occurring beneath a transmission line which runs east-west on the western flank of Companion Hill.

There is about $450 \mathrm{~m}$ of conglomerate exposed on Companion Hill. It is generally a poorly-sorted chert conglomerate with pebbles of white and grey chert set in a sandstone matrix. Quartzite pebbles are moderately abundant. There are rare red and green chert pebbles and very rare basic igneous rock fragments. The chert pebbles are generally less than $1 \mathrm{~cm}$ across with the larger pebbles tending to be better rounded than the smaller ones. There are some coarser layers with pebbles up to $5 \mathrm{~cm}$ across. In such layers the coarser pebbles are usually quartzite. There is a one metre thick micaceous siltstone horizon at the point where PMG Road forks near the top of Companion Hi11.

The conglomerate is very poorly bedded with alignment of elongated pebbles outlining the stratification rather than distinct bedding planes. This alignment of pebbles probably indicates a high flow regime at the time of deposition. Rare examples of imbrication indicate a westerly source area.

In the top $30 \mathrm{~m}$ of the section exposed beneath the transmission lines to the west of Companion Hill the conglomerate becomes much coarser with the percentage of quartzite fragments increasing markedly. Quartzite is more abundant than chert at some levels in this part of the section. These quartzite boulders are mostly well rounded and up to $20 \mathrm{~cm}$ across. The chert fragments in these layers are angular and mostly smaller than the quartzite. Only a few chert pebbles are over two cm across, even where the quartzite boulders are up to $20 \mathrm{~cm}$ across, but a few chert boulders are $15 \mathrm{~cm}$ across. This change in pebble content probably indicates a change of source area.

\section{ACKNOWLEDGEMENTS}

J.B. Jago was supported by a grant from the Australian Research Grants Committee. The writers wish to thank Associated Forest Holdings Limited for willing cooperation in allowing access to their forest concessions. Drs. C.D. Branch and A.S. Joyce (South Australian Institute of Technology) are thanked for valuable advice.

\section{REFERENCES}

Banks, M.R., 1956: The Middle and Upper Cambrian Series (Dundas Group and its Correlates) in Tasmania. EL SISTEMA CAMBRICO, Proc. 20th Int. geol. Congr., $2,165-212$.

, 1962: Cambrian System in THE GEOLOGY OF TASMANIA. J. geol. Soc. Aust., $9(2), 127-146$.

Corbett, K.D. and Banks, M.R., 1974: Ordovician Stratigraphy of the Florentine Synclinorium, south west Tasmania. Pap. Proc. R. Soc. Tasm., 107, 207-238.

Jago, J.B., 1972a: The youngest recorded Tasmanian Cambrian trilobites. Search, $3,173-174$.

1972b: Two new Cambrian trilobites from Tasmania. PaZaeonto Zogy, $15,226-237$.

and Daily, B., 1974: The trilobite genus Clavagnostus Howell from the Cambrian of Tasmania, Australia. Palaeontology, 17, 95-109. 
90

\section{Cambrian Stratigraphy of St. Valentines Peak}

Öpik, A.A., 1961: Cambrian geology and palaeontology of the headwaters of the Burke River, Queensland. Bull. Bur. Miner. Resour. Geol. Geophys. Aust., 53.

1967: The Mindyallan fauna of north-western Queensland. Buz2. Bur. Miner. Resour. Geol. Geophys. Aust., 74.

Quilty, P.G., 1971: Cambrian and Ordovician dendroids and hydroids of Tasmania. J. geol. Soc. Aust., 17, 171-189. 